\section{Внешняя торговля Алтайского края. Взгляд через Программу, ретроспективу и текущие проблемы ${ }^{1}$}

Г.Д. КОВАЛЁВА, кандидат Экономических наук, зав. сектором ВЭС Сибири, Институт экономики и организации промышленного производства СО РАН, Новосибирский государственный университет, Новосибирск

E-mail: gdkov@ieie.nsc.ru

В статье анализ внешней торговли Алтайского края представлен в контексте современных наиболее острых проблем на фоне ситуации в России и Сибирском федеральном округе. Высоко оценивается роль управления и регулирования ВЭД региона на основе программного подхода. Обсуждаются внешние и внутренние .

Ключевые слова: внешняя торговля регионов, управление, экспорт,

импорт, экспортная квота, стратегия, программа, монополия во внешней торговле, приграничное сотрудничество

Наш институт по заданию администрации Алтайского края занимался разработкой Комплексной программы развития его внешнеэкономической деятельности (ВЭД) на период 1998 2005 гг. Огромная, трудоемкая работа заняла более двух лет и потребовала не только осознания того, что же такое региональная концепция, стратегия и программа внешнеэкономической деятельности, но и новой организации работ, поиска методики, структуры, формы изложения документа, механизмов адаптации и внедрения. Это был второй наш опыт разработки региональной программы развития ВЭД в тот период, когда еще ни в институте, ни в стране не было серьезных методических и практических наработок именно в региональном контексте.

Опуская многие находки, сопровождавшие нашу работу, отмечу очень важный, на мой взгляд, момент, тем более актуальный сегодня, когда, с одной стороны, осознана необходимость

Статья подготовлена в рамках выполнения работ по проектам IX.87.1.1. Модернизациягосударственногоуправленияпространственным развитием России на основе совершенствования региональной политики, стратеги ческого планирования и межрегиональной интеграции", № 01201352325 иIX.87.1.3. «Экономическая защищенность субъектов Федерации: оценка, влияние на экономическую безопасность России», № 01201352327 программного подхода и планирования на всех уровнях, а с другой - очевидны системные недостатки управления в стране.

Невозможно разработать стратегию и в ее контексте обоснованную и эффективную программу развития региона, в том числе по ВЭД, без глубокого проникновения в экономику региона и без обследования не только участников внешней торговли, но и всей инфраструктуры по её обслуживанию, включая сферы управления, контроля, расчетов, логистики, выставочной отрасли, всех видов услуг и др.

Только работая на местах, можно получить системное представление о состоянии, проблемах, реальных векторах развития и изложить это в виде обоснованных стратегических направлений и востребованных программных мероприятий.

Практика заочной разработки программных документов для многих регионов Сибирского и других федеральных округов внешними (как правило, московскими) исполнителями показала свою порочность и отсутствие результатов для регионов (чего не скажешь о самих исполнителях) [1].

Условия развития экономики и торговли любого региона формируются в контексте состояния экономики всей страны Ситуация очень непростая: появились новые негативные факторы - высокая турбулентность курсов валют (самый важный для внешней торговли фактор), спад деловой активности в ряде стран-контрагентов, сложная политическая ситуация. Ее усугубили проблемы, появившиеся к началу 2015 г. в России. Годовой темп прироста ВВП РФ в 2014 г. опустился до $0,6 \%$ и продолжает падать, снижение инвестиций в основной капитал достигло 3,5\%

Данные о производстве основных товаров в РФ в 2014 г в натуральном измерении свидетельствуют, что рост наблюдался в немногих отраслях, но радует, что в их число, помимо производства угля и нефти, вошли отрасли, которые еще недавно были аутсайдерами. Это животноводство, производство стали, проката черных металлов, сбор зерновых, картофеля, овощей. Отрадно отметить рост посевных площадей в стране, и особенно - значительный вклад Алтайского края.

Снижение инвестиций на $3,5 \%$ в теории означает начало экономического кризиса. В нашем случае - продолжение падения некоторых отраслей. Однако возможны смена тенденции и рост инвестиций в связи с активизацией деятельности Правительства 
РФ по реальному привлечению иностранных, прежде всего - китайских, инвестиций в производство и инфраструктуру.

\section{Снижение объемов внешней торговли}

К концу 2011 г. был исчерпан потенциал роста внешней торговли РФ, обеспеченный мировой конъюнктурой [2]. Тенденцию 2012-2013 гг. можно обозначить как стагнацию, переходящую в последующее падение в 2014-2015 гг. в основном из-за внешних негативных экономических и политических факторов (рис. 1).

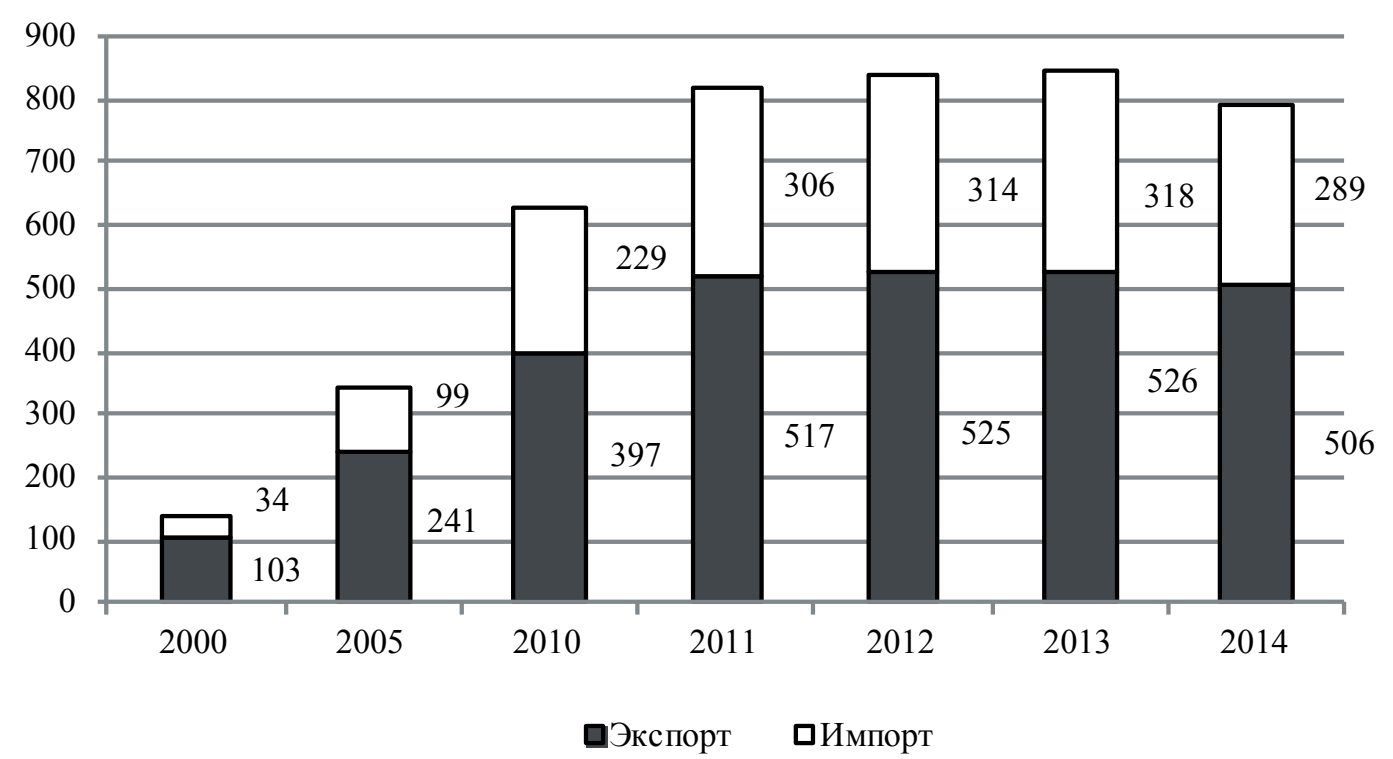

Источник: расчеты автора по данным ФСГС: Российский стат. ежегодник. - М., 2006-2014 гг.; Россия в цифрах. - М., 2015 г.

Рис. 1. Динамика внешней торговли России в 2000-2014 гг., млрд долл. в текущих ценах

Внешнеторговый оборот РФ снизился за 2014 г. на 7\%, в том числе экспорт - на 5,8\%, импорт - на 9,2\%.

Новые приметы: падает доля Евросоюза, на который в 2013 г. приходилось почти $50 \%$ российского товарооборота, а также стран СНГ.

Внешнеторговый оборот РФ с Украиной за год снизился на $28,8 \%$, до уровня 28,2 млрд долл., в том числе экспорт на 26,4\% (17,5 млрд долл.), импорт - на 32,5\% (10,7 млрд долл.). В 2013-2014 гг. после некоторого роста начался спад торговли внутри Евразийского союза, сопровождавшийся ростом доли стран АТР.
Несмотря на то, что санкции привели к сокращению доли торговли России с Евросоюзом до 48,2\%, наиболее агрессивно настроенные страны, напротив, за 2014 г. объемы торговли увеличили: Латвия - более чем на $18 \%$, США - на 5,6\%, и это при довольно значительных объемах внешней торговли: с Латвией свыше 13 млрд долл., с США - более 29 млрд долл. (табл. 1).

Этот и другие примеры свидетельствуют о том, что бизнес в странах проявляет самостоятельность и находит способы это делать, а рынок Евросоюза, как и прочих стран, присоединившихся к санкциям США, следует по-прежнему рассматривать как стратегически важное направление сотрудничества.

Таблица 1. Внешнеторговый оборот России

$$
\text { с основными торговыми партнерами в } 2014 \text { г. }
$$

\begin{tabular}{|l|c|c|c|}
\hline \multicolumn{1}{|c|}{ Внешнеторговый оборот } & Млн долл. 2014 & \% к 2013 & \% к итогу \\
\hline РФ & $\mathbf{7 8 2 9 2 7}$ & $\mathbf{9 3 , 0}$ & $\mathbf{1 0 0}$ \\
\hline В том числе: & & & \\
\hline Страны дальнего зарубежсья & $\mathbf{6 8 7 3 1 4}$ & $\mathbf{9 4 , 2}$ & $\mathbf{8 7 , 8}$ \\
\hline В том числе страны Евросоюза: & 377304 & 90,3 & 48,2 \\
\hline Германия & 70087 & 93,5 & 9,0 \\
\hline Италия & 48469 & 90,0 & 6,2 \\
\hline Латвия & 13266 & 118,2 & 1,7 \\
\hline Нидерланды & 73210 & 96,4 & 9,4 \\
\hline Польша & 23007 & 82,4 & 2,9 \\
\hline Великобритания & 19315 & 78,7 & 2,5 \\
\hline Франция & 18321 & 82,5 & 2,3 \\
\hline Страны АТЭС & 211184 & 101,3 & 27,0 \\
\hline Китай & 88389 & 99,5 & 11,3 \\
\hline Республика Корея & 27311 & 108,5 & 3,5 \\
\hline СшА & 29175 & 105,6 & 3,7 \\
\hline Япония & 30797 & 92,7 & 3,9 \\
\hline Турция & 31099 & 95,0 & 4,0 \\
\hline Государства СНГ & 95612 & $\mathbf{8 5 , 0}$ & $\mathbf{1 2 , 2}$ \\
\hline Среди них страны ЕврАзЭС & 55300 & 91,2 & 7,1 \\
\hline Государства Таможенного союза: & 52555 & 91,1 & 6,7 \\
\hline Беларусь & 31504 & 92,2 & 4,0 \\
\hline Казахстан & 21051 & 89,5 & 2,7 \\
\hline Киргизия & 1817 & 84,9 & 0,2 \\
\hline Таджикистан & 928 & 121,8 & 0,1 \\
\hline Украина & 27862 & 70,4 & 3,6 \\
\hline
\end{tabular}


Рассмотрим динамику торговли с десяткой крупнейших партнеров РФ в 2014 г. более подробно [2]. В 2014 г. на первом месте остался Китай, обеспечивший $11,3 \%$ товарооборота РФ (в 2013 г. - 10,5\%). Нидерланды (второе место) всегда входили в число лидеров с долей 9,4\% (в 2013 г. - 9\%). Далее шли Германия - 9\% (8,9\%), Италия - 6,2\% (6,4\%), Беларусь - 4\% (4,1\%), Турция - 4\% (3,9\%), Япония - 3,9\% (3,9\%), США - 3,7\% (3,3\%), Украина - 3,6\% (4,7\%), Республика Корея - 3,5\% (в 2013 г. $3 \%$ ). Следует отметить, что США поднялись в рейтинге и вошли в первую десятку стран, в сумме обеспечивших почти $60 \%$ внешнеторгового оборота РФ в 2014 г.

Что же падает? Снижаются как экспорт, так и импорт, причем импорт - более быстрыми темпами. Рассмотрим динамику на примере крупных товарных групп.

В товарной структуре экспорта РФ (табл. 2) положительная динамика отмечена всего в четырех случаях; по остальным наблюдалось падение.

Таблица 2. Отраслевая структура экспорта и импорта РФ в 2014 г.

\begin{tabular}{|c|c|c|c|c|}
\hline Товарные группы & $\begin{array}{c}\text { Млн } \\
\text { долл. }\end{array}$ & $\begin{array}{c}\% \text { k } \\
2013 \text { r. }\end{array}$ & $\begin{array}{c}\% \text { к } \\
\text { итогу }\end{array}$ & $\begin{array}{l}\text { Годовая дина- } \\
\text { мика, }(-)(+)\end{array}$ \\
\hline Экспорт РФ, всего & 496944 & 94,2 & 100 & - \\
\hline Топливно-энергетические товары: & 345445 & 92,9 & 69,5 & - \\
\hline нефть сырая & 153878 & 88,6 & 31,0 & - \\
\hline газ природный & 54730 & 81,4 & 11,0 & - \\
\hline Металлы и изделия из них: & 40565 & 99,3 & 8,2 & - \\
\hline черные металлы и изделия из них & 23649 & 100,6 & 4,8 & + \\
\hline цветные металлы и изделия из них & 15758 & 97,7 & 3,2 & - \\
\hline Машины, оборудование и транспортные средства & 26329 & 91,1 & 5,3 & - \\
\hline Продукция химической промышленности, каучук: & 29120 & 94,6 & 5,9 & - \\
\hline удобрения минеральные азотные & 3244 & 96,6 & 0,7 & - \\
\hline удобрения минеральные калийные & 2701 & 123,3 & 0,5 & + \\
\hline Древесина и целлюлозно-бумажные изделия & 11634 & 106,0 & 2,3 & + \\
\hline $\begin{array}{l}\text { Продовольственные товары и сельскохозяйственное } \\
\text { сырье }\end{array}$ & 18906 & 116,5 & 3,8 & + \\
\hline Из них злаки & 7084 & 149,1 & 1,4 & + \\
\hline Импорт & 285982 & 90,8 & 100 & - \\
\hline Машины, оборудование и транспортные средства & 136243 & 89,3 & 47,6 & - \\
\hline Продовольственные товары и с/х сырье & 39715 & 92,0 & 13,9 & - \\
\hline Продукция химической промышленности & 46415 & 92,8 & 16,2 & - \\
\hline
\end{tabular}

Продукция химической промышленности

Источник: URL: http://1prime.ru/state regulation/20150127/801081605. html (дата обращения: 15.06.2015).

\section{Региональная дифференциация}

Одна из серьезных проблем внешней торговли - резкая неестественная дифференциация федеральных округов РФ по уровням регионального экспорта и импорта. Правда, надо отметить условный характер цифр о структуре внешней торговли РФ по федеральным округам, отражающих не реальную информацию о региональном экспорте и импорте, а скорее распределение стоимостного эффекта. Так, Сибирский федеральный округ постоянно занимал в экспорте РФ лишь пятое место, при этом его доля снизилась с 9\% в 2010 г. до 6,9\% в 2013 г. ${ }^{2}$ Но оценки ФСГС как экспорта, так и импорта для СФО, как мы покажем далее, сильно занижены.

А вот доля Центрального федерального округа (49\% в экспорте и $61 \%$ в импорте) и в том числе Москвы (по $43 \%$ в экспорте и импорте) завышена в разы только за счет механизмов учета Напомним, что сложившаяся структура распределения экспорта по округам обусловлена, прежде всего, правилами регистрации головных офисов компаний-экспортеров, а не фактическим производством в регионе продуктов на экспорт, в результате чего реальные объемы и доля экспорта товаров, произведенных в СФО, существенно занижены. Действует хорошо отлаженный мощный канал изъятия финансовых средств из регионов (особенно с развитыми экспортными производствами) в центр. Последствия - дефицит региональных бюджетов вплоть до банкротства

С этих позиций интересно проанализировать соотношения регионов в СФО по экспорту и импорту. Красноярский край и Иркутская область с их минеральными запасами и добывающими и перерабатывающими производствами уступили многолетнее лидерство Кузбассу. Причина - не только изменение правил регистрации всех сделок по экспорту нефти и нефтепродуктов исключительно через центральную энергетическую таможню, где ранее фиксировались лишь трубопроводные поставки. На первом месте - рост добычи угля и его продаж на внешнем рынке. На втором - успешная региональная политика губернатора Кемеровской области, правильно выстроенная в отношениях с федеральным центром и добывающими компаниями. Экспорт кузбасских углей - это экспорт области, следовательно, добывающие компании

2 По данным ФСГС, в 2013 г. на долю СФО в основных фондах РФ приходилось 9,2\% (при этом на долю ЦФО - 33\%). В валовом региональном продукте страны СФО обеспечил 10,3\%. 
зарегистрированы в области, и их налоги на прибыль поступают в региональный бюджет.

Следует с сожалением отметить, что экспорт угля также переведен в энергетическую таможню. Эта структура таможенной очистки была понятна, когда энергетическая таможня (ЦФО) занималась только трубопроводным экспортом, и совершенно необъяснимы затраты на ее расширение по всей стране параллельно с уже созданными таможнями для обработки теперь уже почти всей продукции ТЭК. Для страны в целом это - огромное удорожание обслуживания экспорта. В каких целях - можно только догадываться. Во всяком случае, экспорт ликвидных товаров все более закрывается от региональных администраций. Доля СФО в экспорте РФ в 2013 г., по данным ФСГС, составляла только 6,9\%, в импорте - 2,9 (табл. 3).

Таблица З. Объемы внешней торговли РФ, ЦФО и субъектов СФО в 2013 г., млн долл., в текущих ценах

\begin{tabular}{|l|c|c|c|c|c|}
\hline \multirow{2}{*}{ Регион, федеральный округ } & \multicolumn{2}{|c|}{ Экспорт } & \multicolumn{2}{c|}{ Импорт } & \multirow{2}{*}{ Сальдо } \\
\cline { 2 - 5 } & всего & \% к итогу & всего & \% к итогу & \\
\hline ВСЕГО & 527266,4 & 100,0 & 314967,0 & 100,0 & 212299,4 \\
\hline Центральный & 257296,7 & 48,8 & 192816,6 & 61,2 & 64480,1 \\
\hline Москва & 229461,4 & 43,5 & 134990,7 & 42,9 & 94470,7 \\
\hline Сибирский & $\mathbf{3 6 1 4 3 , 6}$ & $\mathbf{6 , 9}$ & $\mathbf{9 2 1 9 , 9}$ & $\mathbf{2 , 9}$ & $\mathbf{2 6 9 2 3 , 7}$ \\
\hline Алтайский край & $\mathbf{8 3 2 , 3}$ & $\mathbf{0 , 2}$ & $\mathbf{5 0 4 , 1}$ & $\mathbf{0 , 2}$ & $\mathbf{3 2 8 , 2}$ \\
\hline Забайкальский край & 277,6 & 0,1 & 533,9 & 0,2 & $-256,3$ \\
\hline Иркутская обл. & 8166,9 & 1,5 & 1173,4 & 0,4 & 6993,5 \\
\hline Кемеровская обл. & 12658,1 & 2,4 & 1054,0 & 0,3 & 11604,1 \\
\hline Красноярский край & 7868,4 & 1,5 & 2100,6 & 0,7 & 5767,8 \\
\hline Новосибирская обл. & 1691,8 & 0,3 & 2164,0 & 0,7 & $-472,2$ \\
\hline Омская обл. & 872,7 & 0,2 & 529,8 & 0,2 & 342,9 \\
\hline Респ. Алтай & 26,7 & 0,0 & 13,5 & 0,0 & 13,2 \\
\hline Респ. Бурятия & 1299,7 & 0,2 & 163,1 & 0,1 & 1136,6 \\
\hline Респ. Тыва & 0,2 & 0,0 & 15,2 & 0,0 & $-15,0$ \\
\hline Респ. Хакасия & 1806,1 & 0,3 & 573,9 & 0,2 & 1232,2 \\
\hline Томская обл. & 643,2 & 0,1 & 394,5 & 0,1 & 248,7 \\
\hline
\end{tabular}

Источник: данные ФСГС.

Для Алтайского края эта проблема не очень актуальна - на территории нет крупных московских компаний. Но будут. Как только животноводство и растениеводство достигнут значительных масштабов в экспорте - придут внешние компании, и история повторится, если... Если не противодействовать, используя административный ресурс (как это удается А. Тулееву в Кемеровской области).

Соотношение внешней торговли регионов СФО наглядно представлено на рис. 2

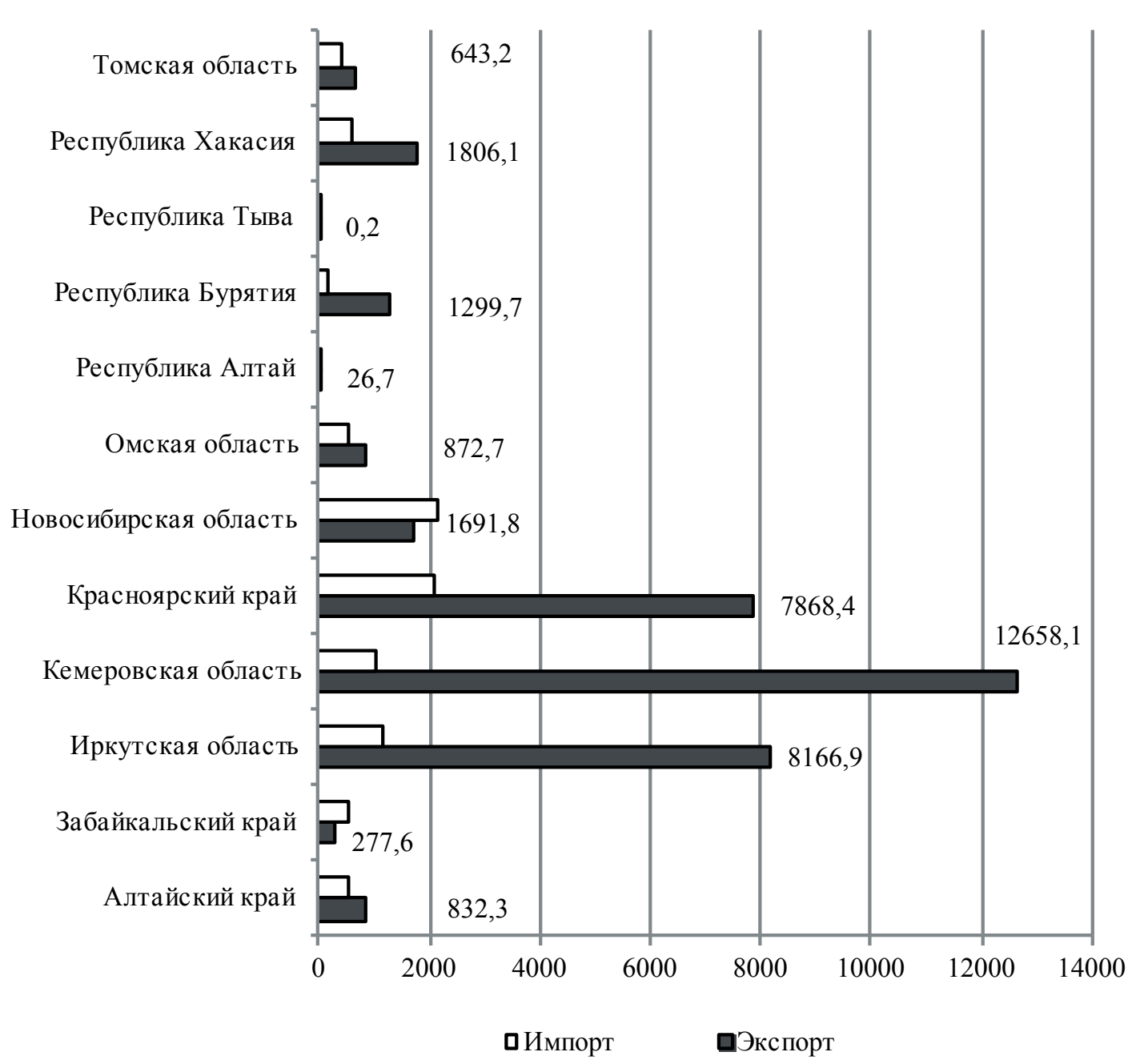

Рис. 2. Экспорт и импорт субъектов СФО в 2013 г., млн долл. в текущих ценах

Алтайский край значительно уступал по объемам экспорта и импорта другим регионам, занимая лишь восьмое место как в экспорте, так и в импорте в $2013 \Gamma^{3}$ и девятое - по темпам роста экспорта за 2005-2012 гг. Экспорт края рос почти вдвое медленнее, чем по России в целом, скорость роста импорта края также

${ }^{3}$ ВРП надушунаселения в РФ составлял в 2005 г. 151 тыс. руб., в 2012 г. 435 тыс. руб. В СФО, по данным ФСГС, этот показатель достигал в 2005 г. 100 тыс. руб., в 2012 г. - 267 тыс. руб. В Алтайском крае в 2005 г. ВРП на душу населения был всего 53 тыс. руб., в 2012 г. - 154 тыс. руб. 
была ниже, она составляла примерно 4/5 от российского показателя. Притом, что экспорт Алтайского края в 1997 г. достигал 181 млн долл., в 2005 г. он уже превысил 744 млн долл., а за 20052012 гг. вырос в 1,2 раза - до 863 млн долл. Импорт в 1997 г. был на уровне 175,5 млн долл., в 2005 г. - 205,3 млн долл., а в 2012 г. превысил 557 млн долл., т. е. вырос за 2005-2012 гг. в 2,7 раза (в СФО, по данным ФСГС, экспорт за 2005-2012 гг. вырос всего в 1,4 раза, импорт - в 2,6 раза).

При сопоставлении внешней торговли регионов в пересчете на душу населения положение Алтайского края ухудшается: в 2012 г. на душу населения приходилось всего 359 долл./чел. в экспорте и 231 долл./чел. - в импорте (в России - 3672 и 2196 долл./чел.; в СФО - 1844 и 545 долл./чел.).

Столь низкие показатели Алтайского края объясняются недостатком природных ресурсов и обвалом промышленности в конце прошлого века, поэтому темп роста его внешней торговли с учетом экономической специфики следует оценивать как достижение. Алтайский край успешно развивается как житница страны и использует перспективные возможности развития экспорта зерновых и экологически чистых высококачественных продуктов.

Отношение экспорта (импорта) к объему ВРП (экспортная/ импортная квота) позволяет оценить вовлеченность экономики во внешнюю торговлю. Для Сибирского федерального округа экспортная квота, рассчитанная даже по заниженным данным ФСГС, всегда была относительно высокой. В 2012 г. она достигала $21 \%$, что всего на 5 п. п. ниже российского показателя. При этом импортная квота для СФО постоянно была чрезвычайно низкой - только $6 \%$ при $16 \%$ в среднем по России.

Низкие квота и доля СФО в импорте страны - на уровне $3 \%$ также связаны с расширяющейся практикой монополизации со стороны центра. В статистике расчетов по таможенным данным импорт фиксируется в том регионе, где зарегистрирован импортер. Поэтому доля Центрального федерального округа растет, достигнув к 2013 г. уже $62,1 \%$ от всего объема импорта в страну. Но это не означает, что весь объем ввезенных товаров потребляется на территории ЦФО. Основная масса импортированных компаниями ЦФО потребительских товаров и продукции производственного назначения поступает в регионы страны по каналам межрегионального обмена и теряется внутри статистики по межрегиональным отгрузкам. Это не только затрудняет оценку импортозависимости регионов и выявление для них основных рискообразующих импортных товаров, но и лишает регионы эффектов импортной деятельности, особенно от ввоза высоколиквидных товаров. Фактическую степень импортозависимости регионов можно оценить, если фиксировать объемы потребления ими импортных товаров с учетом импорта, ввезенного в страну другими регионами.

\section{Сырьевая направленность экспорта}

В Сибирском федеральном округе, по экспертным оценкам, выполненным в уточненной базе данных за наиболее показательный 2011 г., на долю продукции ТЭК, металлов и изделий из них, древесины и целлюлозно-бумажных изделий приходилось свыше 90\% в стоимости экспортных товаров и свыше 95\% в суммарном весе экспортных грузов (табл. 4). В структуре регионального импорта на тот момент определяющими были доли машин, оборудования и транспортных средств и продуктов химической промышленности.

Таблица 4. Товарная структура экспорта и импорта СФО в 2014 г., млн долл.

\begin{tabular}{|l|c|c|c|c|c|}
\hline \multirow{2}{*}{\multicolumn{1}{|c|}{ Группа товаров }} & \multicolumn{2}{|c|}{ Экспорт } & \multicolumn{2}{c|}{ Импорт } & Сальдо \\
\cline { 2 - 7 } & млн долл. & \% & млн долл. & \% & млн долл. \\
\hline ВСего & $\mathbf{3 3 4 6 8 , 2}$ & $\mathbf{1 0 0}$ & $\mathbf{6 6 9 4 , 9}$ & $\mathbf{1 0 0}$ & $\mathbf{2 6 7 7 3 , 3}$ \\
\hline Продовольственные и с/х сырье & 291,4 & 0,9 & 618,5 & 9,2 & $-327,1$ \\
\hline Минеральные, кроме ТЭК & 358,9 & 1,1 & 10,7 & 0,2 & 348,3 \\
\hline Топливно-энергетические & 14022,7 & 41,9 & 140,3 & 2,1 & 13882,4 \\
\hline Продукция химической промышленности & 1391,7 & 4,2 & 1987,0 & 29,7 & $-595,4$ \\
\hline Кожевенное сырье, пушнина и изделия из них & 6,8 & 0,0 & 9,7 & 0,1 & $-3,0$ \\
\hline Древесина и целлюлозно-бумажные изделия & 3756,7 & 11,2 & 59,1 & 0,9 & 3697,6 \\
\hline Текстиль, текстильные изделия и обувь & 7,7 & 0,0 & 298,5 & 4,5 & $-290,9$ \\
\hline Металлы и изделия из них & 11726,9 & 35 & 493,5 & 7,4 & 11233,4 \\
\hline Машины, оборудования и транспортные средства & 1597,4 & 4,8 & 2745,4 & 41 & $-1148,0$ \\
\hline Другие товары & 308,0 & 0,9 & 332,0 & 5 & $-24,0$ \\
\hline
\end{tabular}

Даже на таком агрегированном уровне для СФО очевидно, что продажи на внешнем рынке угля, древесины, целлюлознобумажных изделий и металлов зависят от внешней конъюнктуры, а импортозависимость следует изучать в сферах поставок 
продовольственных товаров и сельскохозяйственного сырья, продукции химической промышленности, машин и оборудования.

В 2014 г. ситуация практически не улучшилась, сохранились все негативные последствия, связанные с сырьевой ориентацией экспорта СФО.

\section{Географические связи. Распределение}

\section{экспорта и импорта сФО по странам}

В 2014 г. экспорт из Сибирского федерального округа осуществлялся в 133 страны (125 стран дальнего зарубежья и в восемь - СНГ). На экспорт в страны дальнего зарубежья приходилось 91,7\%, в том числе на Нидерланды - 17\% (5703,3 млн долл.), Китай - 15,6\% (5249,9), Японию - 10\% (3362,7 млн долл.). Далее идут Республика Корея (2037,4 млн долл.), Тайвань $(1871,9)$, Турция $(1788,9)$, Соединенное Королевство $(1674,4)$, Украина $(1557,5)$, США $(1276,7)$ и Германия $(941,2$ млн долл.).

В первую десятку по объемам экспорта из СФО (а это 76\% всего экспорта округа) из стран СНГ вошла только Украина. Четыре страны из этого списка поддерживают антироссийские санкции, остальные четыре развивают отношения с РФ и одна Япония - в целом придерживается нейтралитета.

Восточная ориентация экспорта СФО очевидна. Следует отметить значительные объемы торговли с Японией, Южной Кореей и Тайванем. С учетом роста экспорта в Китай эти оценки можно расценивать как гарантию внешнего спроса на товары СФО в ближайшей перспективе.

В импорте СФО на страны дальнего зарубежья приходилось $87,4 \%$. Первое место занимает Китай (2415,9 млн долл.), далее идут Украина $(723,7)$, Германия $(699,1)$, США $(366,3)$, Австралия $(312,6)$, Франция $(243,4)$, Япония $(199,5$, Италия $(142,8)$ Финляндия $(123,2)$, Республика Корея (104,2 млн долл.). Среди первых 10 стран рейтинга (это 81\% всего регионального импорта, ввезенного из 128 стран мира) зону нашего риска формируют семь, и среди них Украина находится на втором месте рейтинга импорта, что представляет опасность. В сложившейся ситуации следует положительно оценивать значительные масштабы импорта из Китая.

Роль стран СНГ в торговле СФО по многим товарным позициям остается решающей. На рынок стран СНГ (без учета
Беларуси и Казахстана) в экспорте продовольствия из СФО приходилось 33,5\%, кожевенного сырья, пушнины и изделий из них - 15,3\%, древесины и целлюлозно-бумажных изделий $15,6 \%$, текстиля, изделий из него и обуви - 56,7\%, машин, оборудования и транспортных средств - 40,9\%. По остальным товарным позициям страны СНГ занимали в экспорте СФО 7-8\%

В импорте из стран СНГ в СФО на продукты топливноэнергетического комплекса приходилось $61,2 \%$, продукты химической промышленности - 27,5\%, текстиль, изделия из него и обувь - 7,3\%, продовольственные товары и сельхозсырье 2,6\%. В таблице 5 приведены итоговые за 2014 г. соотношения в торговле СФО со странами СНГ.

Таблица 5. Экспорт и импорт СФО в торговле

со странами СНГ в 2014 г., млн долл.

\begin{tabular}{|l|c|c|c|c|}
\hline \multirow{2}{*}{\multicolumn{1}{|c|}{ Страна СНг }} & \multicolumn{2}{|c|}{ Экспорт } & \multicolumn{2}{c|}{ Импорт } \\
\cline { 2 - 5 } & млн долл. & $\%$ & млн долл & $\%$ \\
\hline Всего & 2783,6 & 8,3 & 843,7 & 12,6 \\
\hline В том числе: & & & & \\
\hline Азербайджан & 160,1 & 0,5 & 35,9 & 0,5 \\
\hline Армения & 50,6 & 0,2 & 1,0 & \\
\hline Киргизия & 211,9 & 0,6 & 5,5 & 0,1 \\
\hline Молдова & 7,0 & & 2,0 & \\
\hline Таджикистан & 148,3 & 0,4 & 1,3 & \\
\hline Туркмения & 42,5 & 0,1 & 0,3 & \\
\hline Узбекистан & 605,7 & 1,8 & 74,0 & 1,1 \\
\hline Украина & 1557,5 & 4,7 & 723,7 & 10,8 \\
\hline Всего мир & $\mathbf{3 3 4 6 8 , 2}$ & $\mathbf{1 0 0}$ & $\mathbf{6 6 9 4 , 9}$ & $\mathbf{1 0 0}$ \\
\hline
\end{tabular}

В торговле Сибирского федерального округа важную позицию занимала Украина: на нее приходилось в 2014 г. 4,7\% всего экспорта и 10,8\% - импорта. Прекращение торговли с Украиной для СФО оценивается более чем в 2,28 млрд долл.

\section{Неразвитость приграничного сотрудничества}

Целью приграничного сотрудничества является социально-экономическое развитие приграничных муниципальных образований повышение благосостояния их населения посредством укрепления взаимовыгодных дружественных связей с соседними регионами сопредельных государств. И здесь ключевые слова - муниципальные образования. Потенциал приграничного сотрудничества, если 
он реализуется, открывает колоссальные возможности для решения как экономических, так и социальных задач приграничных территорий. Сегодня этот потенциал на восточных границах практически не востребован, и эффект от приграничного сотрудничества можно оценивать как колоссальную упущенную выгоду за период с начала реформы внешнеэкономической деятельности в России.

В Сибирском федеральном округе из 12 регионов семь имеют статус приграничных. Это почти $30 \%$ его площади ${ }^{4}$, здесь проживает 50\% населения округа. Положение на приграничных территориях остается чрезвычайно серьезным. Так, среднедушевой доход в 2013 г. во всех регионах был значительно ниже среднероссийского, особенно в Алтайском крае и в республиках Тыва и Алтай (табл. 6).

Таблица 6. Социально-экономические показатели приграничных регионов СФО в 2013 г.

\begin{tabular}{|c|c|c|c|c|c|}
\hline \multirow[t]{2}{*}{ Регион } & \multirow{2}{*}{$\begin{array}{c}\text { Средне- } \\
\text { душевой } \\
\text { доход, } \\
\text { тыс. руб. }\end{array}$} & \multirow{2}{*}{$\begin{array}{c}\text { Номинальная } \\
\text { заработная } \\
\text { плата, тыс. } \\
\text { руб. }\end{array}$} & \multirow{2}{*}{$\begin{array}{c}\text { Уровень } \\
\text { безрабо- } \\
\text { тицы,\% }\end{array}$} & \multicolumn{2}{|c|}{$\begin{array}{c}\text { Оборот розничной } \\
\text { торговли на душу } \\
\text { населения }\end{array}$} \\
\hline & & & & $\begin{array}{l}\text { тыс. } \\
\text { руб. }\end{array}$ & $\begin{array}{l}\text { \% к рос- } \\
\text { сийскому }\end{array}$ \\
\hline PФ & 25,9 & 29,8 & 5,5 & 164,9 & 100 \\
\hline Сибирский федеральный округ & 20,5 & 26,4 & 7,2 & 132,4 & 80 \\
\hline Респ. Алтай & 14,8 & 20,7 & 11,5 & 84 & 51 \\
\hline Респ. Бурятия & 20,8 & 26,0 & 8 & 134 & 81 \\
\hline Респ.Тыва & 13,5 & 25,1 & 19,3 & 54 & 33 \\
\hline Алтайский край & 16,0 & 18,0 & 8,3 & 118 & 72 \\
\hline Забайкальский край & 19,9 & 27,3 & 10,5 & 116 & 71 \\
\hline Новосибирская обл. & 22,6 & 25,5 & 5,9 & 159 & 96 \\
\hline Омская обл. & 21,4 & 24,8 & 6,8 & 149 & 91 \\
\hline
\end{tabular}

Источник: расчеты автора по данным ФСГС. Российский стат. ежегодник. - М., 2014.

Проблема заключается в том, что до сих пор не принят закон о приграничном сотрудничестве, который обсуждается с 2004 г. [3]. Прошло более 10 лет, как проект был внесен на рассмотрение в Государственную думу, разработан уже новый, но и он во многом не отвечает нуждам регионов.

${ }^{4}$ Для СФО приграничное сотрудничество обусловлено географическим фактором - протяженной внешней границей (7769 км); граница с Казахстаном составляет 2698 км (36\% всей границы РФ - Казахстан), с Монголией 3485 км (100\% соответственно) и Китаем - 1586 км (38\%).
Приграничное сотрудничество остается нереализованным в главном - не осваивается потенциал муниципального уровня, не формируется экономическое взаимодействие прилегающих к границе муниципалитетов с их приграничными соседями, не узаконены их права и формы взаимодействия. Контакты на муниципальном уровне сводятся, в основном, к соглашениям о развитии культурных связей в области народного творчества спорта, образования. Тем не менее развитие приграничного сотрудничества может стать катализатором роста не только внешней торговли непосредственно приграничной территории, но и всей экономики региона [4].

\section{Стратегии развития Алтайского края: уроки на будущее}

С учетом всех отмеченных факторов вернемся к сопоставлению стратегий развития Алтайского края. В далеком 1997 г. был выполнен прогноз, по которому, при условии реализации программы, экспорт должен был к 2005 г. достигнуть 1 млрд долл., что в расчете на одного человека составило бы 380 долл. в год Предполагалось также, что импортозамещение сырья и продуктов его переработки в крае только в растениеводстве и животноводстве удвоит ВРП.

В программе 1997 г. отмечалось следующее: «Алтайский край располагает большим, но мало востребованным потенциалом именно в промышленности, уникальными научными и селекционными научными разработками, редкой для Сибири возможностью производства высококачественного сырья для пищевой и легкой промышленности. Реализация экспортно-импортного потенциала восстановит и разовьет значение края не только для регионов Сибири, но и соседних стран».

Сегодня, через 18 лет, в отчетах и докладах представителей власти края подчеркиваются большие достижения именно в этом направлении, прогнозируются еще более значительные результаты в области развития сельского хозяйства, повышения его значимости для всей страны и расширения присутствия на внешних рынках.

Географические приоритеты внешнеэкономических связей Алтайского края в 1997 г. были выстроены следующим образом. 
«1. Совершенствование экономических связей с Казахстаном и восстановление на взаимовыгодной основе экономического сотрудничества с Узбекистаном, Таджикистаном, Кыргызстаном и в перспективе - с Туркменией. (В структуре экспорта края в страны Средней Азии машиностроение составляло 63\%, химические товары - 18-20\%, легкая промышленность $-5 \%$, строительные материалы - 4\%.)

2. Западное направление - Беларусь, Украина, Молдова.

3. Формирование на новых принципах экономического взаимодействия с Монголией и Китаем.

4. Восстановление экономического взаимодействия со странами Восточной Европы и расширение позиций в Западной Европе.

5. Продвижение на рынки стран Ближнего Востока и Турции, стран АТР, Вьетнама.

6. Целенаправленное восстановление торговли со странами Закавказья».

В программе было подчеркнуто: «Федеральное значение имеет организация в крае эффективной приграничной торговли на базе создания законодательной и инфраструктурной среды».

Еще 18 лет назад было отмечено то, что и сегодня остается актуальным: «Экономический спад принял такие масштабы, когда оживление деловой активности становится невозможным без кардинального реформирования всей системы управления. В области ВЭД это проявляется в объективной необходимости расширения полномочий и функций местных органов управления. Те регионы, в которых органы управления, осознав важность расширения внешней торговли и оптимизации ее экономического эффекта, перестроили свою деятельность, от выжидательной позиции по отношению к центру перешли к активному лоббированию региональных интересов, расширили сферу координации и включили в круг своих интересов активную поддержку участников ВЭД, увеличили за последние годы объемы внешнеторгового оборота в 2-4 раза».

Что же изменилось с тех пор? За время работы программы к 2005 г. экспорт края вырос более чем в четыре раза. Если в 1997 г. он составлял 181,7 млн долл., то в 2005 г. уже 744,1 млн долл., а еще через семь лет, в 2012 г., достиг 832,3 млн долл. За этот период были реализованы многие положения программы. Доля стран СНГ составляла в 1997 г. в экспорте края даже без учета Казахстана $22 \%$. В 2014 г., когда экспорт края сократился до 460,8 млн долл., доля стран СНГ без учета Казахстана достигла уже 40,3\%. Из них 17\% приходилось на Узбекистан, 8\% - на Украину. Выросла доля Китая в экспорте - с 5\% до 10\%. Диверсификация деятельности привела к тому, что алтайская продукция нашла спрос и на рынках США, чья доля в экспорте края в 2014 г. достигла 14\%. Эти тенденции были обоснованы программой 1998-2005 гг.

Реалистичность программной стратегии подтверждает и тот факт, что даже в условиях 2014 г., несмотря на спад, край имел в отдельных отраслях высокие показатели внешней торговли, особенно впечатляющие - в производстве продукции сельского хозяйства и пищевой промышленности. Открылись новые возможности выхода на внешние рынки с экологически чистыми продуктами питания, и в этом направлении Алтайский край имеет безграничные возможности. Новой особенностью становится выдвижение на передний план завоевания внутреннего рынка и успешное избавление от засилья иностранных конкурентов.

Как и 18 лет назад, сохраняются те же географические приоритеты. Изменились потребности в масштабах торговой экспансии на рынки стран Средней Азии и Казахстана, добавляется важность и актуальность развития производственной кооперации с большинством из них, особенно в рамках Евразийского экономического союза (ЕАЭС). В ближайшие годы вероятно расширение китайских инвестиций в инфраструктуру края, развитие взаимного туризма, расчетной системы, транспортных коммуникаций.

Представляется важным инвестиционный вход в экономику Монголии. Это добыча полезных ископаемых, совместное производство товаров (кашемир, экологически чистые мясные и молочные консервы на монгольском сырье; производство необходимого оборудования для монгольской энергетики, фармацевтика и др.)

${ }^{5}$ Статистика торговли с Казахстаном не входит в таможенную статистику в силу единого таможенного пространства с Россией, а с января 2015 г. с началом сотрудничества в рамкахЕАЭС, пришедшего на смену ЕврАзЭС. 
Но самое главное - остро назрел переход к конструктивному управлению: речь идет не только о повышении эффекта от администрирования, но и снижении потерь от бездеятельности, внедрении в управленческую практику реальной ответственности на фоне управленческой смелости и масштабности мышления.

Оценивая весь спектр возможностей Алтайского края в новых условиях, следует ожидать в ближайшей перспективе ускорения развития его экономики и внешней торговли даже с учетом внешних негативных факторов (а в некоторых аспектах - благодаря им)

\section{Литература}

1. Ковалёва Г.Д. Мониторинг внешнеэкономической деятельности Новосибирской области // Актуальные проблемы развития Новосибирской области и пути их решения: сб. науч. тр. В 2-х ч. Ч. 1: Проблемы и перспективы экономического развития Новосибирской области / Под ред. А. С. Новосёлова, А. П. Кулаева; ИЭОПП СО РАН. Новосибирск, 2014. - С. 191-268.URL: http://lib.ieie.nsc.ru/docs/2014/ AktualProbIRazvNovosib2014/10Kovaleva.pdf

2. URL: http://1prime.ru/state_regulation/20150127/801081605.html, (дата обращения: 15.06.2015).

3. Проект федерального закона «О приграничном сотрудничестве в Российской Федерации» внесен Государственную думу постановлением Совета Федерации от 15 июля 2004 г. (регистрационный номер 75537-4). URL: http://www.gosbook.ru/node/74057 опубликован 4.06.2013 г. (дата обращения: 15.07.2015).

4. Ковалёва Г.Д. Муниципальное управление в организации приграничного сотрудничества в Сибирском федеральном округе // Региональное и муниципальное управление социально-экономическим развитием в Сибирском федеральном округе / Под ред. А. С. Новосёлова; ИЭОПП СО РАН. - Новосибирск, 2014. - Гл. 12. - С. 319-340.URL: http://lib.ieie.nsc.ru/docs/2014/RegionIMunicUpravl/Pt12Kovaleva.pdf 